\title{
PERAN HUMAS PEMERINTAH SEBAGAI FASILITATOR KOMUNIKASI PADA BIRO HUMAS PEMPROV KALIMANTAN SELATAN
}

\author{
Belinda Devi Larasati Siswanto ${ }^{1}$, Firda Zulivia Abraham² \\ ${ }^{1}$ Biro Humas, Sekretariat Daerah Provinsi Kalimantan Selatan. \\ Jl. Aneka Tambang, Komplek Sekertariat Daerah Prov. Kalimantan Selatan, Banjarbaru \\ ${ }^{2}$ Balai Pengkajian dan Pengembangan Komunikasi dan Informatika Banjarmasin \\ Jl. Yos Sudarso No.29, Banjarmasin, Kalimantan Selatan 70119 \\ No. Telp./HP: ${ }^{1} 082153517979,{ }^{2} 0812531529$ \\ E-mail: ${ }^{1}$ belindadevi@yahoo.co.id, ${ }^{2}$ fird007@kominfo.go.id
}

Naskah diterima tanggal 13 April 2016, direvisi tanggal 31 Mei 2016, disetujui tanggal 20 Juni 2016

\section{THE ROLE OF GOVERNMENT PUBLIC RELATIONS AS FACILITATORS COMMUNICATION IN BUREAU OF PUBLIC RELATION AT SOUTH KALIMANTAN PROVINCE}

\begin{abstract}
As the windows of information, communication facilitator role in Government Public Relation (GPR) serve as all-in-and-out of information from or to publics. For that, this research be held to find about the communication facilitator role on GPR of South Kalimantan Provincial Government. This research intends to knowing communication facilitator role to provide information to people and otherwise. This research uses qualitative approach with descriptive case study method, the data collection through observation and depth interview with informants purposively selection. The research result showing the communication facilitator role in GPR Bureau is not optimal, caused by unavailable information who can be accessed by the public or the otherwise. Government Information which should can be accessed at government official website or at the social media not be optimized by the GPR Bureau well as the Main Information Management and Documentation Officer (IMDO) whose role is held by the GPR Bureau of the information that should be accessible through the website, is not available. This contrasts with some Local Work Unit function only a Subsidiary IMDO, but they were ready to provide information to the public through a website managed.
\end{abstract}

Keywords: facilitator, communication, information, role, government public relation.

\begin{abstract}
Abstrak. Sebagai pintu informasi, peran fasilitator Komunikasi pada Humas berfungsi sebagai tempat keluar dan masuknya berbagai informasi dari dan untuk masyarakat. Penelitian ini dilakukan untuk mencari peran fasilitator komunikasi pada Humas Pemprov Kalsel dan untuk mengetahui peran fasilitator komunikasi untuk memberikan informasi kepada masyarakat dan sebaliknya. Penelitian ini menggunakan pendekatan kualitatif dengan metode studi kasus deskriptif, teknik pengumpulan data melalui observasi dan wawancara mendalam dengan pemilihan informan secara purposif. Hasil penelitian menunjukkan peran fasilitator komunikasi pada Biro Humas tidak maksimal, ketidaktersediaan informasi yang dapat diakses oleh publik menjadi penyebab tidak maksimalnya peran humas sebagai fasilitator komunikasi dari masyarakat ke pemerintah, maupun sebaliknya. Informasi pemerintahan yang seharusnya dapat diakses pada website maupun media sosial yang telah tersedia tidak berjalan maksimal, begitu juga dengan Pejabat Pengelola Informasi dan Dokumentasi (PPID) Utama yang perannya dipegang oleh Biro Humas, informasi yang seharusnya dapat di akses melalui website, tidak tersedia. Ini berkebalikan dengan beberapa Satuan Kerja Perangkat Daerah (SKPD) yang


fungsinya hanya PPID Pembantu, tetapi mereka telah siap memberikan informasi ke publik melalui website yang dikelola.

Kata kunci: fasilitator, komunikasi, informasi, peran, humas pemerintah.

\section{PENDAHULUAN}

Pemerintah Daerah dewasa ini terus dituntut untuk dapat memberikan pelayanan publik yang lebih efektif. Pemerintah selaku penyelenggara pelayanan publik yang seharusnya semakin memiliki integritas tinggi dalam melaksanakan fungsi sebagai pelayan masyarakat dalam memberikan keterbukaan informasi, hingga kini masih menjadi "barang yang langka". Tidak terkecuali setelah Undang-Undang Keterbukaan Informasi Publik (UU KIP) dikeluarkan, pemerintah semakin diawasi oleh masyarakat.

Marshall McLuhan mengatakan bahwa media itu "The Extension of Man" (media itu perluasan manusia). Bisa dikatakan media adalah kepanjangan tangan dari manusia, apa yang diinginkan oleh manusia dapat diperpanjang jangkauannya oleh media, terlebih lagi oleh media hibrida yang dapat menerobos ruang dan waktu untuk dapat mengaksesnya (Aprilia et al., 2014).

Pemerintahan, baik kementerian, pemerintah provinsi, pemerintah kabupaten/kota, bahkan pemerintahan desa diharuskan untuk mengembangkan pemerintahan elektronik (pemerintahan-el/eGovernment). E-Government mengharuskan pemanfaatan secara maksimal TIK terutama website untuk menyediakan kecepatan dan kemudahan serta lebih efisien untuk mengakses dan untuk menyediakan informasi/layanan kepada publik (Lee, 2010).

Lee et al. (2012) menjelaskan, memberikan pelayanan publik merupakan hal yang paling penting dan diperlukan oleh humas pemerintah, tidak hanya sekedar mengatur strategi komunikasi yang efektif demi mewujudkan misi dari pemerintahan semata. Informasi publik merupakan salah satu aspek kunci untuk akuntabilitas pemerintah, praktisi humas pemerintah perlu membangun komunikasi eksternal dalam menyampaikan informasi publik yang dapat digunakan untuk memajukan kinerja pemerintahan itu sendiri.

Dalam aktivitasnya untuk menyentuh seluruh lapisan masyarakat pada pelayanan informasi publik, pemerintah mengandalkan peran dari humas pemerintah. Peran praktisi public relations sebagai fasilitator komunikasi adalah bertindak sebagai perantara dan membantu manajemen dengan menciptakan kesempatan-kesempatan untuk mendengar apa kata publiknya dan menciptakan peluang agar publik mendengar apa yang diharapkan manajemen (Dozier dan Broom, 1995).

Peran ini juga menjaga komunikasi dua arah dan memfasilitasi komunikasi dengan menyingkirkan rintangan dalam hubungan dan menjaga agar saluran komunikasi tetap terbuka. Selain itu bertindak sebagai sumber informasi dan juru komunikasi antara organisasi dan publik. Tujuannya adalah memberi informasi yang dibutuhkan oleh baik itu manajemen maupun publik untuk membuat keputusan demi kepentingan bersama (Cutlip et al., 2006).

Dalam konteks ini, peran fasilitator komunikasi dapat dilihat dari indikator Biro Humas, yakni menjadikan pemerintah sebagai pendengar suara dari masyarakat dan membuat suara pemerintah didengar oleh masyarakat melalui penyiaran kegiatan pemerintah melalui berbagai media komunikasi. Indikator selanjutnya yakni pendengar yang peka dan broker (perantara), interpreter dan mediator komunikasi antara organisasi dan publiknya juga menjaga komunikasi dua arah dan menjaga agar komunikasi selalu tetap terbuka.

Sementara dalam tupoksi PPID utama terdapat penilaian yang termasuk dalam indikator tersebut yakni mengoordinasikan dan mengonsolidasikan pengumpulan bahan informasi dan dokumentasi dari Satuan Kerja Perangkat Daerah (SKPD) Pemprov Kalsel dan menyimpan, menyediakan, serta memberi pelayanan informasi kepada publik kemudian 
membuat laporan pelayanan informasi seperti jumlah pemohon infomasi, permintaan informasi yang ditolak dan diterima, alasan penolakan dan waktu yang dibutuhkan dalam proses permohonan informasi publik. Dari latar belakang di atas dapat ditarik sebuah permasalah yaitu, bagaimana peran Biro Humas dan PPID Provinsi Kalimantan Selatan sebagai fasilitator komunikasi?

\section{LANDASAN KONSEP}

Welkinson (2012) dalam penelitiannya mengenai peran humas pada Dewan Perwakilan Rakyat Republik Indonesia (DPR RI) dengan menggunakan Teori Dozier menemukan bahwa aktivitas humas DPR RI lebih mengarah kepada peran fasilitator komunikasi. Ini sesuai dengan implementasi Undang-Undang No. 14 Tahun 2008 Tentang Keterbukaan Informasi Publik.

Penelitian berikutnya dilakukan oleh Hidayati (2014) pada Badan Pemeriksa Keuangan (BPK) RI. Hidayati menganalisis penelitiannya dengan memakai elaborasi konsep standar kewajiban pelaksanaan UU No.14 Tahun 2008 di badan publik. Penelitian ini menghasilkan temuan yang menegaskan hasil temuan Welkinson sebelumnya. Penemuan tersebut berupa realita bahwa humas pemerintah berposisi sebagai fasilitator komunikasi. Humas BPK RI disimpulkan sangat berperan dalam memberikan masukan dan kebijakan mengenai keterbukaan informasi publik.

Dalam Practice of Government Public Relations (Lee et al., 2012) dijelaskan bahwa memberikan pelayanan publik merupakan hal yang paling penting dan diperlukan oleh humas pemerintah, dan tujuan dalam menyampaikan informasi publik tersebut adalah untuk memajukan kinerja pemerintahan itu sendiri.

Seperti yang diungkapkan oleh Cutlip et al. (2006), dua premis fundamental tentang pentingnya pemerintah mempraktikkan public relations adalah (1) Pemerintah yang demokratis harus menyampaikan kegiatannya kepada masyarakat; (2) Administratif pemerintahan yang efektif memerlukan partisipasi dan dukungan aktif dari masyarakat. Dari dua pernyataan itu menunjukkan bahwa pemerintahan yang demokratis perlu mempraktikkan pertukaran informasi agar tercipta partisipasi masyarakat.

Telah banyak diungkapkan, penelitian mengenai peran public relations penting karena penelitian tentang peran memungkinkan untuk menghubungkan pekerjaan public relations dengan identifikasi lebih luas dari seberapa baik departemen humas yang terstruktur dalam organisasi (Dozier et al., 1995), sementara itu Holtzhausen, Petersen, dan Tindall (dalam Boudreaux, 2005) mendefinisikan peran sebagai tindakan berulang yang dilakukan untuk menetapkan sistem praktik atau model.

Penelitian terdahulu mengenai peran public relations oleh Dozier dan Broom (1995), menghasilkan empat peran public relations yang sampai saat ini masih relevan untuk dipakai dalam penelitian dan kemudian oleh mereka pula tahun 1992 dibagi kembali peran tersebut menjadi dua bagian, yaitu peran sebagai public relations (communication manager role) yakni sebagai fasilitator komunikasi.

Peran praktisi public relations bertindak sebagai perantara dan membantu manajemen dengan menciptakan kesempatan-kesempatan untuk mendengar apa kata publiknya dan menciptakan peluang agar publik mendengar apa yang diharapkan manajemen (Dozier and Broom, 1995). Toth mendefinisikan peran ini adalah sebagai pendengar yang peka dan broker (perantara), interpreter, dan mediator komunikasi antara organisasi dan publiknya (Boudreaux, 2005). Peran ini juga menjaga komunikasi dua arah dan memfasilitasi komunikasi dengan menyingkirkan rintangan dalam hubungan dan menjaga agar saluran komunikasi tetap terbuka. Selain itu bertindak sebagai sumber informasi dan juru komunikasi antara organisasi dan publik. Tujuannya adalah memberi informasi yang dibutuhkan oleh baik itu manajemen maupun publik untuk membuat keputusan demi kepentingan bersama (Cutlip et al., 2006).

Konteks peran humas yang menjadi fokus dalam penelitian ini adalah pelaksanaan segala aktivitas Biro Humas pemerintah 
Provinsi Kalimantan Selatan dalam pelayanan informasi publik.

\section{METODE PENELITIAN}

Jenis penelitian ini adalah studi kasus deskriptif dengan pendekatan kualitatif, pada Biro Humas Pemerintah Provinsi Kalimantan Selatan dalam melayani informasi publik. Studi kasus deskriptif dalam penelitian ini merupakan studi kasus intrinsik yang berangkat dari keinginan peneliti untuk memahami suatu permasalahan. Lokasi penelitian kantor Biro Humas Sekretariat Daerah Provinsi Kalimantan Selatan Jl. Aneka Tambang Banjarbaru, pada bulan Maret sampai dengan Mei 2015.

Teknik pengumpulan data pertama yakni observasi, dilakukan untuk mengamati website www.kalselprov.go.id kemudian website PPID utama ppid.kalselprov.go.id yang pengelolaannya menjadi tanggung jawab Biro Humas Kalsel, berikut juga media online seperti facebook "Biro Humas Kalimantan Selatan" dan twitter @ kalselprov.

Sumber data kedua yaitu dokumentasi. Dalam penelitian ini, data dokumentasi yang dicari berasal dari dua sumber, yaitu dari dalam internal Biro Humas dan dari eksternal Biro Humas. Kategori dokumen berupa surat, e-mail pelayanan informasi publik, agenda, laporan kemudian kliping berita, dan artikel dari media massa. Kemudian pengumpulan data yakni dengan wawancara mendalam menggunakan wawancara semi terstruktur.

Penentuan key person yang dijadikan narasumber dalam penelitian ini dengan memerhatikan tingkat kesesuaian (relevansi) antara kedudukan/jabatan dan keterlibatan informan dalam proses keterbukaan informasi publik. Informan-informan yang dirasa dapat membantu peneliti untuk mencapai tujuan penelitian, seperti yang dapat dilihat pada tabel 1.

Teknik penyajian data dilakukan dengan cara penguraian dalam deskripsi katakata (naratif) dan juga disajikan data formal berupa tabel kegiatan atau aktivitas humas. Dalam penelitian ini, penyajian data menggunakan teknik penjodohan pola, yaitu dengan membandingkan data pola peran Humas atau aktivitas yang senyatanya terjadi di Biro Humas Provinsi Kalsel dengan pola peran Humas menurut proposisi atau prediksi alternatif dari peneliti berdasarkan teori Dozier dan Broom (1995) dan Cutlip et al. (2006).

Validitas dilakukan menggunakan triangulasi sumber yakni membandingkan konsistensi hasil temuan dalam satu metode penelitian kualitatif dari observasi, wawancara, dan dokumen. Menganalisis pembicaraan dan mencocokkannya dengan data umum yang ada.

Penelitian ini memiliki sejumlah batasan. Berdasarkan ruang lingkupnya, penelitian ini hanya mengkaji peran humas di provinsi saja. Sehingga, pembahasan persoalan peran humas di kabupaten/kota tidak akan dibahas. Analisis peran humas yang digunakan dalam penelitian ini hanya memotret peran humas di Provinsi Kalimantan Selatan dengan dimensi peran dan maknanya yang sudah ditetapkan dalam konsep penelitian.

Tabel 1

Daftar Informan Penelitian

\begin{tabular}{ll}
\hline \multicolumn{1}{c}{ Nama Informan } & \multicolumn{1}{c}{ Kedudukan Informan } \\
\hline Abdul Haris Makkie & Kepala Biro Humas Provinsi Kalsel \\
Zainuddin & Kepala Bagian Pengolahan Informasi \\
Khairil Saleh & Kepala Sub Bagian Penyiaran dan Layanan Pers \\
Syah Yulianda & Kepala Sub Bagian Pelayanan Informasi dan Data \\
Allen & Petugas PPID Pembantu pada Dinas Pekerjaan Umum Provinsi Kalsel \\
Bahrommajie & Kepala Seksi Telekomunikasi Dishubkominfo Provinsi Kalsel \\
Reza & Wartawan dan Kepala Siaran Radio Abdi Persada \\
Mufith Afif & Direktur LSM LKOMDEK \\
\hline
\end{tabular}




\section{HASIL PENELITIAN DAN PEMBAHASAN}

\section{Penyebaran Informasi Kegiatan Pemerintah Melalui Media}

Pelaksanaan penyiaran informasi kegiatan pemerintah melalui media komunikasi. Media komunikasi yang dipakai dalam penyiaran ini adalah media massa baik cetak maupun elektronik, serta media online. Menurut Kepala Sub Bagian Penyiaran dan Pelayanan Pers, Khairil Saleh, yang pertama yakni Biro Humas pada kegiatannya dalam pelaksanaan penyebaran informasi kegiatan daerah dengan cara pembuatan serta penyebaran press release dan keterangan langsung yang diberikan oleh Gubernur maupun melalui Biro Humas kepada media massa yang tujuannya agar dapat didengar dan dilihat oleh masyarakat luas. Namun dari penelitian yang dilakukan kegiatan press release sudah tidak lagi dipergunakan oleh Biro Humas. Biro Humas mengganti kegiatan press release tersebut menjadi kegiatan pembuatan naskah berita saja.

Pemberitaan melalui media massa, selain digunakan untuk penyebaran press release dan naskah berita yang dibuat oleh Biro Humas, Biro Humas juga menggunakan media massa sebagai media komunikasi dalam penyiaran informasi kegiatan pemerintah, dengan terlebih dahulu Biro Humas juga menyertakan kegiatan Jurnalistik Wartawan yakni aktivitas yang mengikutsertakan wartawan pada suatu kegiatan pemerintahan dengan outputnya berupa release pemberitaan pemerintahan dari media massa mengenai kegiatan pemerintahan yang diliput media tersebut.

Dalam sekali peliputan kegiatan pemerintahan, beberapa wartawan dari media massa yang telah tergabung dalam anggota press room Pemerintah Provinsi Kalsel, hanya sekitar 5 (lima) media massa yang diundang namun diatur secara bergilir oleh Biro Humas. Dari keterangan Kepala Sub Bagian Penyiaran dan Pelayanan Pers Biro Humas Provinsi Kalsel, Khairil Saleh, terdapat beberapa media besar seperti Banjarmasin Post, Radar Banjar yang merupakan jaringan media di bawah grup
Jawa Post dan Kompas Gramedia perusahaan besar nasional sering tidak bersedia ikut serta dalam kegiatan jurnalistik wartawan oleh Biro Humas ini, namun biasanya mereka tetap pergi pada kegiatan tersebut hanya saja dengan menggunakan dana dari media mereka sendiri.

Dijelaskannya lagi, pada media yang berada di bawah jaringan Nasional tersebut, Biro Humas tidak meminta agar berita mengenai kegiatan pemerintahan itu diberitakan sesuai dengan kejadian yang ada, biasanya yang terjadi adalah media tersebut lebih memilih memberitakan hal lain yang lebih menarik dibandingkan berita seremonial pemerintahan saja, media massa tersebut memilih pemberitaan yang memunyai nilai jual tinggi mengingat posisi mereka yang berada di bawah anak perusahaan media nasional.

Selain itu juga, dalam upayanya memberikan peluang agar masyarakat mengetahui kegiatan pemerintah, Biro Humas memasukkan dengan sengaja berita pemerintahan dalam media massa yang telah dipilih. Pemberitaan Pemerintah yang dimasukkan oleh Biro Humas yakni berupa Laporan Khusus, Rubrik Khusus atau Advetorial. Materi berita yang dimasukkan biasanya seputar kegiatan khusus pemerintahan seperti Hari Ulang Tahun Provinsi Kalsel atau kumpulan kegiatan pemerintahan khusus dalam beberapa bulan pada tahun yang sama.

Biro Humas juga melakukan kegiatan melalui media elektronik seperti televisi dan radio. Pada televisi, Biro Humas menyiarkan kegiatan pemerintahan di TVRI Kalsel satu kali dalam seminggu, program yang disiarkan dinamakan Pemda Menjawab. Format dalam program Pemda Menjawab ini, yakni berupa dialog interaktif dengan masyarakat melalui sambungan telepon dan atau dihadirkan narasumber bandingan selain dari pemerintah. Narasumber yang hadir menjadi pembicara merupakan pejabat pada Dinas atau Badan di lingkup Provinsi Kalsel bahkan Gubernur dapat menjadi narasumber dalam dialog interaktif ini.

Kemudian tema yang diangkat pada dialog ini disesuaikan dengan isu-isu yang 
berkembang di Provinsi Kalsel sehingga disesuaikan pula dengan pejabat Dinas atau Badan yang akan menjadi narasumber pada dialog tersebut. Penentuan tema yang akan diangkat pada dialog ini tidak hanya datang dari Biro Humas namun juga dari pihak TVRI Kalsel pun dapat menyumbangkan ide untuk topik yang dapat dibahas dalam program Pemda Menjawab dikarenakan TVRI Kalsel termasuk media yang rutin menyoroti kegiatan pemerintahan di Kalsel. "Nah kalau Pemda Menjawab di TVRI itu termasuk penyiaran melalui media massa yang ada sesi interaktifnya dengan masyarakat. Jadi bisa betakun (bertanya) langsung lewat telepon, lalu kepala Dinas atau yang hadir disitu bisa langsung menjawab sesuai tema lah. Karena soal tema itu ditentukan oleh Humas bisa jua pang (juga sih) masukan dari TVRI membantui (ikut membantu)" (Khairil Saleh, Kepala Sub Bagian Penyiaran dan Layanan Pers).

Menurut Kepala Sub Bagian Penyiaran dan Layanan Pers Biro Humas, Khairil Saleh, program ini dimaksudkan untuk menyampaikan kebijakan pemerintah Provinsi Kalsel, serta untuk menyerap aspirasi yang berkembang di masyarakat. Kegiatan ini telah diselenggarakan sejak tahun 2010 bersama dengan TVRI Kalsel. Program dialog ini merupakan bentuk Biro Humas dalam memberikan peluang komunikasi antara pemerintah dengan masyarakatnya.

Dijelaskan juga, selain program dialog rutin di TVRI, Biro Humas juga menyiarkan kegiatan pemerintahan melalui Radio Abdi Persada. Radio Abdi Persada sendiri merupakan Radio milik pemerintah daerah Provinsi Kalsel yang saat ini juga berada dalam pengadministrasian Biro Humas Provinsi Kalsel. Dalam program yang Radio Abdi Persada siarkan, program yang melibatkan Biro Humas adalah Dialog Persada dan Ronda Kota. Format program dalam Dialog Persada yakni berupa dialog interaktif para Kepala Dinas atau Badan maupun pejabat pemerintah Provinsi Kalsel lainnya dengan masyarakat. Para Kepala Dinas atau Badan menjadi narasumber secara bergilir sesuai tema yang diajukan oleh Biro
Humas maupun pihak Radio Abdi Persada. Dalam program ini, diciptakan komunikasi interaktif antara narasumber dan para pendengar di Radio Abdi Persada. Program ini disiarkan setiap dua kali setiap minggu dengan menghadirkan narasumber dari pejabat di lingkup Pemerintah Provinsi Kalsel.

Dari penuturan Reza, melekatnya Radio Abdi Persada dengan Pemprov Kalsel dan keberadaan Radionya sendiri yang induknya Biro Humas, maka penjadwalan narasumber yang akan hadir dalam program Radio memerlukan persetujuan dari Biro Humas untuk dapat melakukan dialog dengan topik yang disusun oleh Radio Abdi Persada. Biro Humas sebagai penyandang dana berikut juga sebagai 'klien' dari Radio Abdi Persada dalam program dialog ini menginginkan pemberitaan penyiaran informasi yang informatif dan memberikan citra positif pemerintahan di mata masyarakat melalui dialog interaktif lewat siaran radio.

Menurut Kepala Bagian Pengolahan Informasi Biro Humas Provinsi Kalsel, Zainuddin, materi atau naskah berita yang diolah oleh Biro Humas biasanya oleh media massa bisa dijadikan berita sesuai dengan kegiatan pemerintahan yang materinya diberikan oleh Biro Humas, namun bisa juga dijadikan berita lain dengan sudut pandang yang berbeda atau bahkan bisa juga berita tersebut tidak dimunculkan oleh media massa dikarenakan oleh banyak hal terkait dengan kebijakan media massa itu sendiri. Dalam hal ini Biro Humas tidak dapat melakukan intervensi kepada media massa tersebut dikarenakan penempatan berita merupakan hak dari media massa, apalagi ditambah tidak adanya perjanjian atau kesepakatan untuk pemuatan berita dari Biro Humas. Namun bagi beberapa media massa yang memiliki stok berita terbatas maka berita dari Biro Humas tersebut menjadi alternatif pelengkap item berita yang mereka miliki.

Media komunikasi kedua setelah media massa baik cetak dan elektronik, Biro Humas juga menggunakan beberapa media online yakni pertama, Website resmi pemerintah www.kalselprov.go.id yang dikelola oleh 


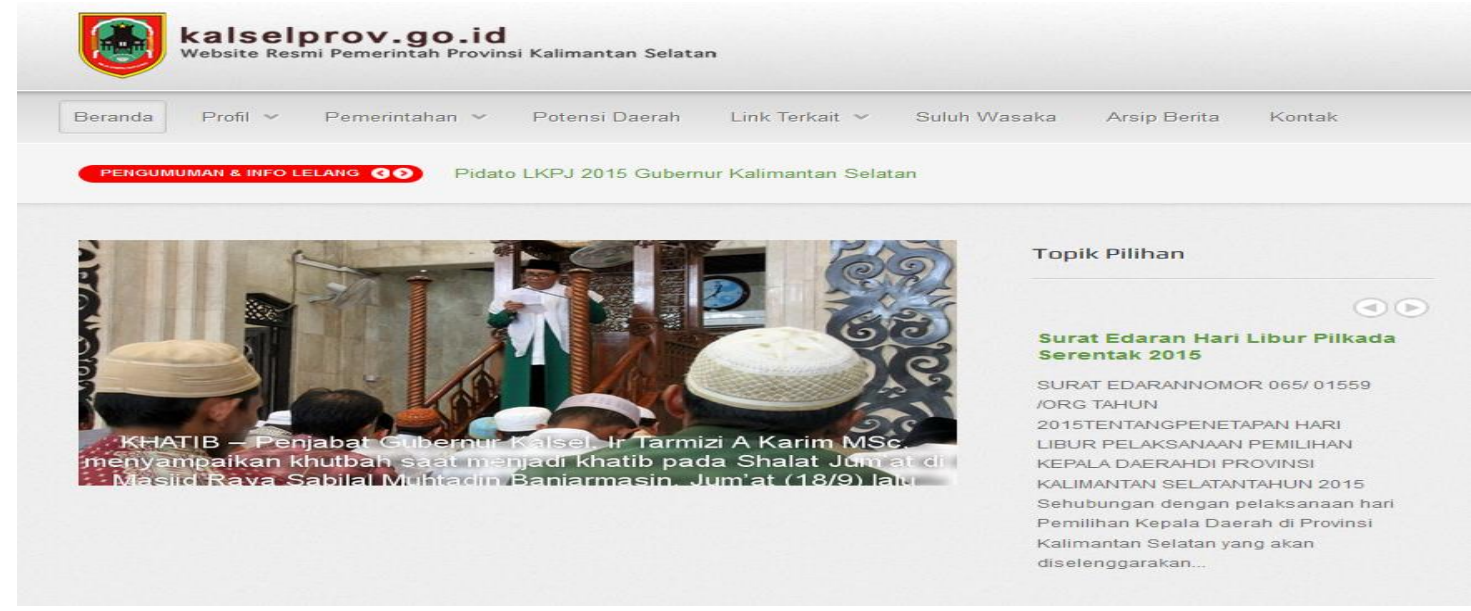

Sumber: www.kalselprov.go.id

Gambar 1 . Website Resmi Pemprov Kalsel yang dimanfaatkan sebagai Media Komunikasi

Biro Humas. Website tersebut berisikan informasi kegiatan dan kebijakan serta pengumuman mengenai pemerintahan. Tampilan laman website dapat dilihat pada gambar 1.

Kemudian website tersebut dikembangkan agar dapat diakses melalui smartphone dengan aplikasi Android yang bernama Kalsel Feed. Media online kedua ini merupakan aplikasi android yang menyajikan informasi pemerintahan bersamaan dengan beberapa posting (memuat berita) dalam website resmi Pemerintah Provinsi Kalsel. Apabila mem-posting berita pada website maka otomatis akan ter-posting juga dalam aplikasi android tersebut

Pada tahun 2010, Biro Humas Provinsi Kalsel membuat media komunikasi online ketiga yang masih aktif dipakai sampai saat ini yakni facebook "Biro Humas Pemerintah Provinsi Kalsel". Pada facebook berita yang tampilkan biasanya lebih singkat dari website. Berita pada facebook hanya berupa berita tautan (link) ke website resmi pemerintah Provinsi Kalsel.

Tidak cukup dengan facebook, Biro Humas kemudian membuat akun twitter @ kalselprov, yang merupakan media online keempat setelah facebook. Pada twitter ini, berisikan pengumuman singkat tentang pemerintahan maupun kegiatan yang akan berlangsung serta informasi ringan mengenai pemerintahan.

Penggunaan media komunikasi dalam pelaksanaan penyiaran informasi pemerintah oleh Biro Humas Provinsi Kalsel sudah menggunakan beberapa media komunikasi baik cetak, elektronik, dan online. Namun penggunaan media komunikasi yang beragam oleh Biro Humas ini tidak diimbangi dengan beragamnya informasi yang diberikan untuk setiap media komunikasi terutama pada media online. Pemberitaan yang dimuat di dalam facebook, twitter dan aplikasi android sama dengan yang ada pada website. Bahkan hanya berupa tautan berita ke website, sehingga terkesan hanya seperti pesan berantai. Masing-masing media online dapat dimaksimalkan penggunaannya disesuaikan dengan karakteristik berita, pengguna dan tujuannya. Sehingga berbagai media online tersebut saling melengkapi. Sejauh ini dengan yang dilakukan oleh Biro Humas terkesan memberikan informasi pemerintahan yang seragam melalui berbagai media komunikasi tanpa dapat memberikan perbedaan tujuan dan fungsi yang menonjol di antara semua media komunikasi yang digunakan.

Dari seluruh media baik media massa dan penyiaran di televisi maupun radio yang digunakan Biro Humas untuk penyebaran informasi, Biro Humas telah mencoba untuk menciptakan ruang publik sebagai tempat komunikasi yang dilakukan dalam wilayah sosial yang bebas dari sensor serta penyuntingan dan dominasi. Ini sejalan dengan pemikiran Habermas (1991), yang melihat dunia publik sebagai wilayah yang memungkinkan pembentukan opini publik tempat semua orang terlibat di dalamnya. Penggunaan media online untuk keperluan penyebaran informasi berjalan sesuai dengan 
tujuan e-government yakni terciptanya hubungan secara elektronik antara pemerintah dan masyarakat sehingga masyarakat dapat mengakses berbagai informasi mengenai pemerintahan dan menunjang good government dan keterbukaan informasi (Anwar dan Oetojo S, 2004).

\section{Ketidaktersediaan Informasi Publik yang Memadai Untuk dan Oleh Masyarakat}

\section{Melalui Bagian Pengelolaan Data} Elektronik (PDE) pada Biro Humas melakukan penyaringan berita atau informasi kegiatan pemerintah dan informasi atau berita yang terpilih kemudian ditampilkan pada website resmi pemerintah Provinsi Kalsel serta juga pada aplikasi android, facebook, dan twitter. Pada keempat media komunikasi online yang dipergunakan oleh Biro Humas Provinsi Kalsel tersebut, masyarakat dapat bebas mengakses informasi atau berita pemerintahan Provinsi Kalsel yang diinginkan.

Pada perkembangannya, Biro Humas yang telah ditetapkan sebagai PPID utama provinsi, membuat website PPID (ppid.kalselprov.go.id). Namun sampai penelitian ini dilakukan, website PPID belum berjalan seperti seharusnya. Tampilan laman depan dari website PPID dapat dilihat pada gambar 2.

Menurut Kepala Sub Bagian Pelayanan Informasi dan Data Biro Humas Provinsi Kalsel, Syah Yulianda, hal ini diakibatkan oleh dua hal yakni pertama, ketersediaan informasi publik dari SKPD di lingkup Pemprov Kalsel masih minim pada Biro Humas, karena banyak SKPD yang belum mengumpulkan dan mengklasifikasikan informasi yang dimilikinya, padahal website PPID telah selesai dibuat dan siap untuk dioperasikan. Kedua, website PPID belum diputuskan pengelolaannya oleh Gubernur Kalimantan Selatan. Sejauh ini Biro Humas hanya membantu untuk membuatkan website PPID Provinsi Kalsel, mengingat Biro Humas yang juga sebagai PPID utama.

Sementara itu, jika Biro Humas sebagai PPID utama belum sama sekali menggunakan website PPID nya sebagai media yang dapat diakses masyarakat untuk memperoleh informasi publik, berbeda dengan dua instansi yang lebih dulu siap. Dinas Peternakan dan Dinas Perhubungan Komunikasi dan Informatika telah memasukkan fungsi mereka sebagai PPID pembantu dengan membuat aplikasi PPID serta permintaan informasi dan daftar informasi publik melalui website instansi maupun website PPID pembantu pada instansi mereka. Aplikasi link layanan publik dan PPID ditampilkan pada beranda website sehingga masyarakat mudah menemukan dan mengaksesnya. Di dalam link PPID tersebut terdapat waktu pelayanan, daftar informasi publik yang bersifat umum disertai dengan surat untuk melakukan perizinan dan beberapa kebijakan, serta surat

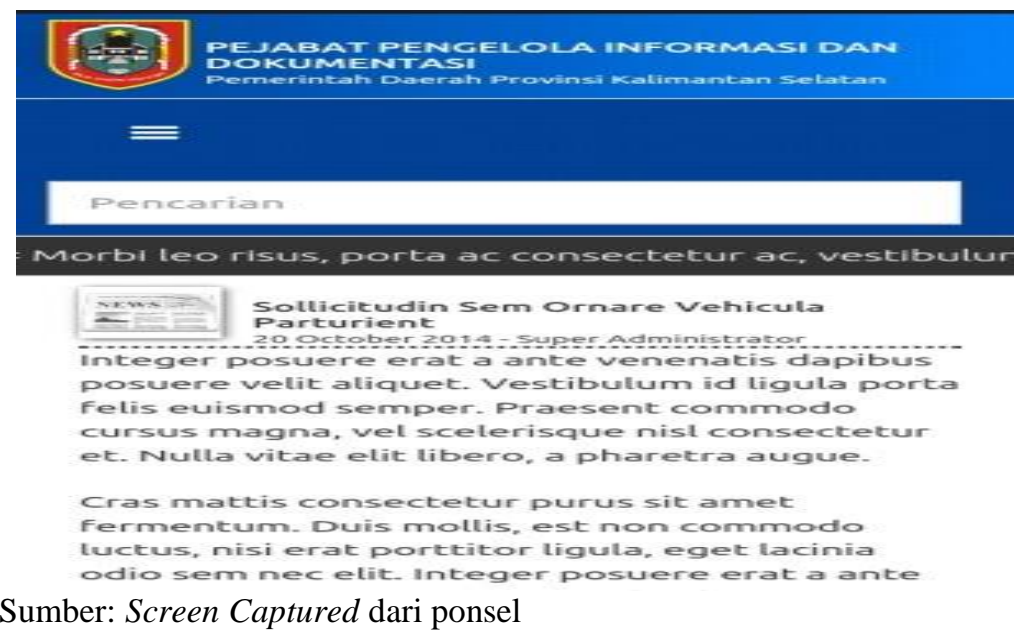

Gambar 2. Tampilan laman PPID Kalsel Yang belum Dipergunakan 
permohonan informasi. Laman website Dinas Peternakan Provinsi Kalimantan Selatan dapat dilihat pada gambar 3 .

Sementara itu, Dinas Perhubungan Komunikasi dan Informatika telah membuat sendiri website PPID pembantu mereka. Walaupun belum terdapat daftar informasi publik. Namun dalam website tersebut tercantum jam layanan informasi publik dan formulir permintaan infromasi yang dapat diunduh pada website mereka. Website PPID Dinas Perhubungan Komunikasi dan Informatika Pemerintah Provinsi Kalsel yang telah Beroperasi dapat dilihat pada gambar 4 . Bersinergi dengan pernyataan Cutlip et al. (2006) dengan UU KIP, seharusnya yang menyediakan informasi dan dokumentasi untuk diakses oleh masyarakat adalah tugas PPID utama, dalam hal adalah Biro Humas. Namun tugas ini tidak dilaksanakan dengan baik oleh Biro Humas. Dilihat dari belum terkumpulnya daftar informasi publik secara terkoordinir oleh Biro Humas dari SKPD maupun dari organisasi Biro Humas sendiri serta masih pasifnya Biro Humas dalam menjalankan website PPID.

Biro Humas dalam acara Bakohumas mengundang semua SKPD di lingkungan Pemerintah Provinsi Kalsel, Humas Kabupaten/Kota di Provinsi Kalsel, dan media cetak, serta elektronik. Sedangkan kegiatan Jumpa Pers merupakan salah satu kegiatan Biro Humas dalam posisinya sebagai perantara komunikasi di pemerintahan. Komunikasi dalam Jumpa Pers ini dilakukan oleh wartawan atau media massa yang tercatat dalam anggota press room pemerintah Provinsi Kalsel dan semua humas/staf yang menagani informasi pada SKPD di lingkup Provinsi Kalsel. Menurut Kepala Bagian Pengolahan Informasi, Zainuddin, kegiatan Jumpa Pers merupakan kegiatan yang memaparkan visi, misi, dan beberapa permasalahan serta solusinya dalam SKPD di lingkup Provinsi Kalsel. Tujuan dari Jumpa Pers ini yaitu meningkatkan koordinasi yang efektif antar unsur masyarakat terutama dalam media massa dan media cetak atau elektronik. Kegiatan Jumpa Pers yang dilaksanakan empat kali dalam setahun ini dihadiri oleh semua media cetak maupun elektronik di Provinsi Kalsel.

Selain dua kegiatan di atas, dibuat juga kegiatan Rapat Koordinasi (Rakor) Komunikasi Kehumasan Pemprov Kalimantan Selatan. Rakor Komunikasi Kehumasan merupakan kegiatan yang melibatkan semua Humas di Kabupaten/Kota dan SKPD Pemprov Kalsel ini berisikan

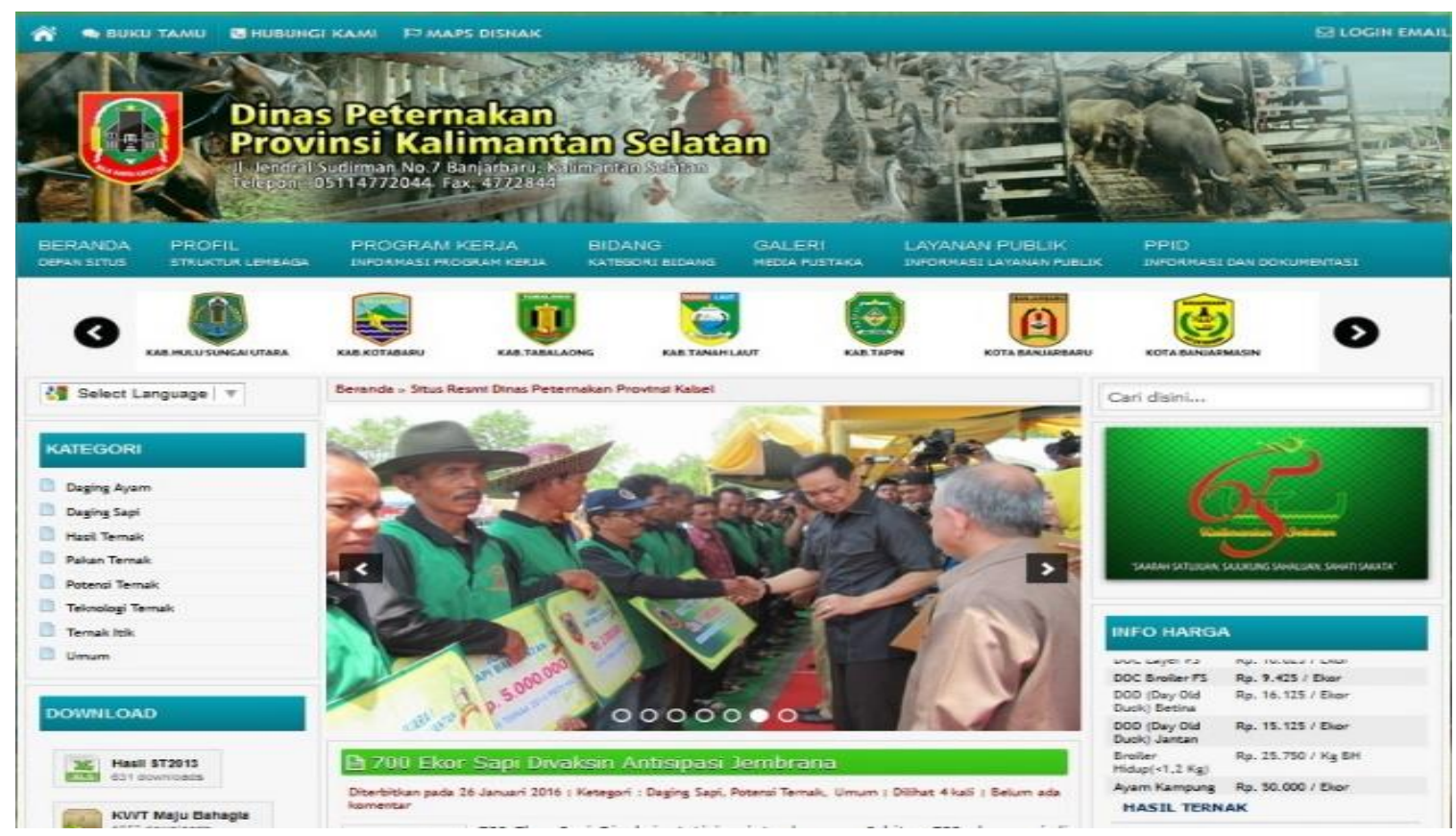

Sumber: Screen Captured pada laman website

Gambar 3. Website Dinas Peternakan Pemerintah Provinsi Kalsel dan Aplikasi Layanan Informasi Publik PPID Pembantu 


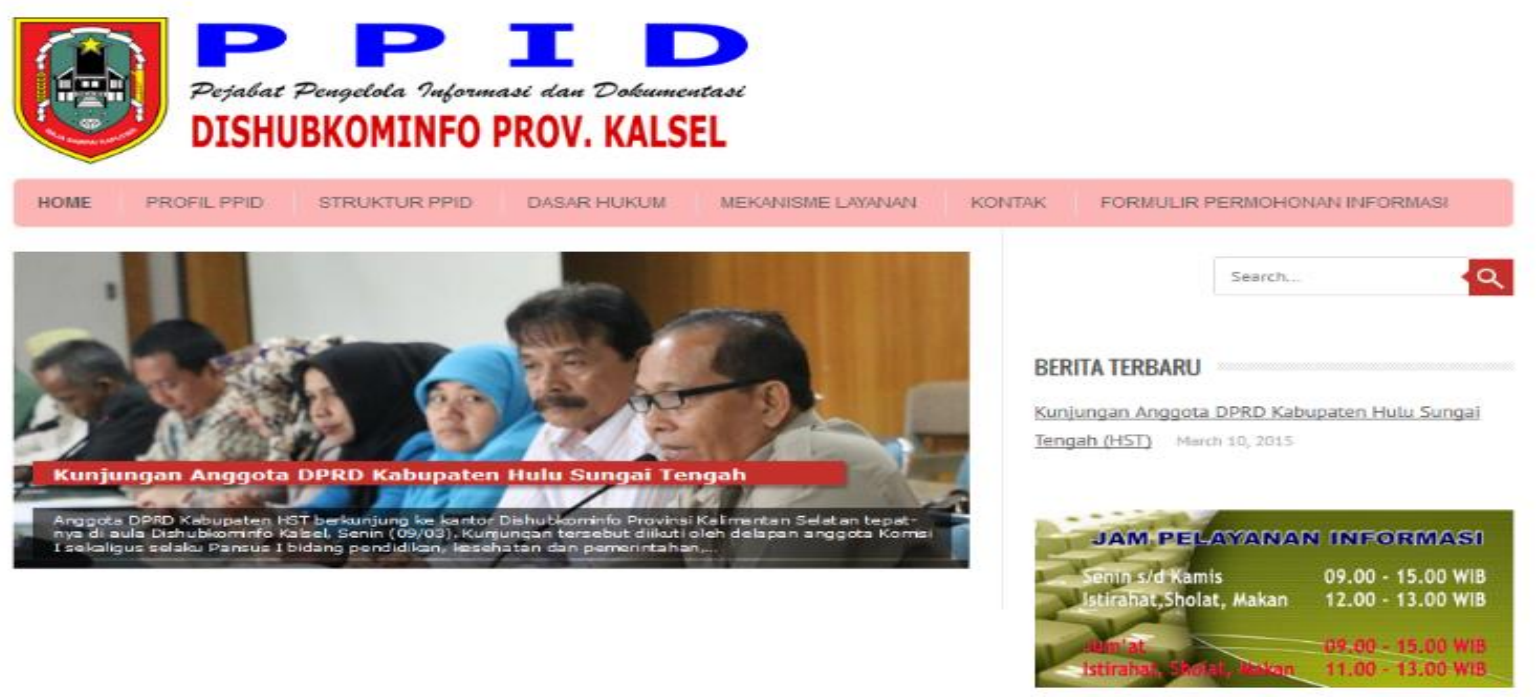

Sumber: Screen Captured pada laman website

Gambar 4. Website PPID Dinas Perhubungan Komunikasi dan Informatika Pemprov Kalsel yang telah Beroperasi

sosialisasi dan penyamaan persepsi antara Biro Humas Provinsi Kalsel dengan Humas Kabupaten/Kota dan instansi di lingkup Provinsi Kalsel. Ketiga kegiatan tersebut sebagai perantara dan mediator komunikasi di pemerintahan. Humas telah menjadi perantara dan mediator komunikasi seperti yang di ungkapkan oleh (Cutlip et al., 2006). Selain itu kemampuan dan pengetahuan dari praktisi Humas diperlukan untuk menjadi perantara komunikasi antar pemerintah dengan masyarakat maupun dengan aparat pemerintah itu sendiri.

Hasil penelitian menunjukkan bahwa praktisi Humas dalam menjalankan kegiatan kehumasannya masih berada pada posisi pasif terutama dalam hal kemampuan menganalisis suatu informasi maupun pemberitaan. Biro Humas cenderung menjalankan program yang sudah terlaksana tanpa memiliki kemauan untuk mengembangkan kegiatan kehumasan dalam posisinya sebagai PPID utama.

\section{Humas sebagai Perantara Komunikasi}

Sebagai fasilitator komunikasi, Humas juga berperan sebagai perantara antarorganisasi dan publik (Boudreaux, 2005). Salah satu kegiatan humas sebagai perantara komunikasi adalah dengan kegiatan koordinasi dan konsolidasi pengumpulan bahan informasi juga dokumentasi dari Satuan Kerja Perangkat Daerah (SKPD)
Pemprov Kalsel. Kegiatan tersebut merupakan salah satu kegiatan yang dilakukan oleh Biro Humas Provinsi Kalsel dengan posisinya sebagai PPID utama Provinsi. Dari observasi yang dilakukan, Biro Humas masih mengusahakan bahan informasi terkumpul dalam waktu dekat. Tercatat sudah dua kali surat permintaan informasi dan penglasifikasian informasi dikirimkan pada setiap SKPD lingkup Provinsi Kalsel Biro Humas yang juga telah melalui persetujuan dan sepengetahuan Sekretaris Daerah Provinsi Kalsel.

Dari dokumentasi yang diperoleh selama penelitian, Biro Humas mengirimkan surat permintaan data informasi kepada semua SKPD melalui PPID pembantu yang telah dibentuk pada setiap SKPD lingkup Provinsi Kalsel pada tanggal 8 Oktober 2014. Pada surat tersebut dijelaskan dasar hukum dari permintaan data informasi oleh Biro Humas serta dipaparkan juga tugas PPID dalam pengelolaan informasi dalam upaya penerapan Undang-Undang Keterbukaan Informasi Publik. Dijelaskan pula bahwa Biro Humas berencana mengembangkan sistem penyediaan layanan informasi dengan membuat Desk Pusat Layanan Data dan Informasi pada Sekretariat Daerah Provinsi Kalsel sehingga diperlukan data informasi dari semua SKPD lingkup Pemprov Kalsel.

Pada surat tersebut diberitahukan juga bahwa PPID utama yakni Biro Humas akan 
datang ke setiap SKPD untuk meminta datadata dasar informasi yang bersifat terbuka sesuai penjelasan UU KIP. Biro Humas dalam hal ini 'menjemput bola' ke setiap SKPD untuk mengambil atau memberitahukan informasi yang harus disiapkan. Data dasar yang diminta yakni:

1. Profil SKPD, sejarah singkat, struktur organisasi, visi, misi, tujuan, kedudukan, tugas dan fungsi, program kerja dan anggaran kegiatan, Sumber Daya Manusia (SDM) (struktur dan fungsional), sarana dan prasarana.

2. Informasi tentang kegiatan dan kinerja seperti Laporan Akuntabilitas Kinerja.

3. Laporan informasi keuangan seperti laporan realisasi anggaran, laporan pendapatan daerah, laporan pertanggungjawaban keuangan, kebijakan dan peraturan daerah terkait

Menurut Kepala Bagian Pengolahan Informasi Biro Humas Provinsi Kalsel, Zainuddin, setelah dua bulan surat tersebut diberikan, namun hanya beberapa SKPD yang menanggapi. Sementara, pada tahun 2013 sampai 2014 Biro Humas telah melakukan beberapa kali koordinasi dan konsolidasi berupa sosialisasi tentang UU KIP pada semua SKPD lingkup Provinsi Kalsel dengan menghadirkan narasumber dari Kementerian Komunikasi dan Informatika RI serta Komisi Informasi Pusat.Menurut Kepala Biro Humas Provinsi Kalsel, Abdul Haris Makkie, hal tersebut dilakukan sebagai langkah awal dalam rangka koordinasi dan konsolidasi pengumpulan bahan informasi dan dokumentasi dari SKPD yang ada di lingkup Provinsi Kalsel dan lebih menjelaskan kembali isi dari UU KIP.

Program kegiatan yang dilakukan Biro Humas yakni: (1) Melaksanakan bimbingan teknis PPID, (2) Penghimpunan Data di SKPD lingkup Pemprov Kalsel, (3) Mengolah data yang sudah terhimpun menjadi informasi yang dapat diakses masyarakat serta mengklasifikasi data yang dikecualikan untuk dibuat dalam Daftar Informasi Publik (DIP), (4) Menyiapkan Standar Operasional Prosedur (SOP) pelayanan informasi publik PPID, (5) Menyiapkan Desk Pusat Layanan Data dan Informasi PPID, (6) Menyiapkan website PPID untuk kemudahan meng-input data dan pemberian layanan informasi melalui jaringan internet. Semua program kegiatan yang dirancang oleh Biro Humas tersebut hampir telah terlaksana semuanya. Namun belum maksimal dan masih berjalan sampai saat ini. Terutama dalam hal penghimpunan data informasi dari SKPD di lingkup Provinsi Kalsel, yang merupakan kunci dari berjalannya fungsi PPID di Provinsi Kalsel.

Dari penjelasan Kepala Bagian Pengolahan informasi Biro Humas Prov Kalsel, Zainuddin, Biro Humas telah beberapa kali memberikan sosialisasi dan juga surat dinas untuk semua SKPD di Kalsel, untuk membentuk PPID berserta kelengkapannya termasuk menghimpun informasi SKPD yang kemudian dapat diklasifikasi sendiri oleh SKPD bersangkutan. Begitu juga Biro Humas telah membagi timtim yang akan menghimpun informasi dari SKPD di Provinsi Kalsel. Namun begitu, respon yang minim dari SKPD atau tidak adanya sanksi maupun kejelasan dalam keterlambatan pengumpulan data informasi, membuat SKPD merasa hal ini bukanlah hal yang mendesak untuk dilaksanakan.

Biro Humas sebagai PPID utama juga tidak membuat kegiatan yang nyata sebagai upaya percepatan pengumpulan informasi sehingga daftar informasi publik untuk setiap SKPD dapat ditentukan dan dapat diakses oleh masyarakat dengan begitu kegiatan pelayanan informasi di Provinsi Kalsel pun dapat berjalan dengan semestinya. Koordinasi antara Biro Humas dan SKPD kurang terjalin dengan baik, koordinasi yang terjalin hanya sebatas sosialisasi, rapat kerja maupun Bimtek. Tidak ada kesinambungan yang nyata dari kegiatan yang telah dilakukan oleh Biro Humas.

\section{Informasi dan Interaktivitas Pelayanan Informasi Kepada Publik}

Biro Humas dalam kegiatannya sebagai PPID utama Provinsi Kalsel menyimpan informasi dan memberi pelayanan informasi kepada publik. Dalam observasi didapat hanya beberapa instansi yang memberikan data. Data itu pun masih berbentuk hardcopy. 
Sedangkan untuk pelayanan informasi bukan hanya hardcopy yang dibutuhkan namun juga softcopy serta pengklasifikasian informasi yang dimaksud dalam UU KIP belum terlaksana sampai pada tingkat Biro Humas Provinsi Kalsel. Saat ini yang direspon oleh SKPD hanyalah sebatas menunjuk PPID untuk SKPD mereka, itupun hanya menunjuk satu orang tidak membentuk struktur organisasi dalam pengelolaan PPID. Hanya Dinas Perhubungan Komunikasi dan Informatika yang telah membuat struktur PPID di organisasinya, sementara SKPD lainnya ada yang hanya menunjuk nama pejabat yang ditunjuk sebagai PPID di instansinya dengan bentuk berupa nota dinas, namun ada juga yang sudah berupa Surat Keputusan dari Kepala SKPD yang bersangkutan.

Biro Humas belum membuat laporan pelayanan informasi seperti jumlah pemohon infomasi, permintaan informasi yang ditolak dan diterima, alasan penolakan dan waktu yang dibutuhkan dalam proses permohonan informasi publik. Saat observasi dilakukan masih belum ada laporan pelayanan informasi namun Biro Humas nantinya tetap melakukan rekap atau membuat laporan dalam hal pelayanan informasi di Pemerintah Provinsi Kalsel. Biro Humas melakukan inventarisasi informasi yang dikecualikan untuk dilakukan uji konsekuensi oleh tim pertimbangan. Inventarisasi informasi ini dilakukan oleh Biro Humas dengan mengumpulkan semua informasi yang ada pada setiap SKPD di lingkup Provinsi Kalimantan Selatan.

Menurut Kepala Pengolahan Informasi Biro Humas Provinsi Kalsel Zainuddin, beberapa Dinas di Provinsi sudah ada yang melakukan tindakan keterbukaan informasi di organisasinya sebelum UU KIP terbit. Namun berupa tindakan atau layanan visual seperti rutin memberikan pengumuman tentang organisasinya di media massa atau melalui layar bahkan perangkat komputer di lobi kantor mereka.

Selain keterlambatan berada pada SKPD lain, Biro Humas juga turut andil dalam lambannya penerapan keterbukaan informasi publik sehingga pelayanan informasi publik tidak dapat dilakukan semestinya oleh Biro Humas. Biro Humas sebagai PPID utama yang merangkum semua daftar informasi publik dari semua SKPD belum berjalan sehingga masyarakat yang menginginkan permintaan informasi lebih memilih untuk memintanya pada instansi atau SKPD yang terkait. Seperti yang telah dijelaskan pada peran kedua Biro Humas sebelumnya yakni LSM memilih untuk meminta informasi pada Dinas terkait, hal ini dikarenakan publik merasa lebih mudah ketika permintaan informasi langsung pada instansi terkait dengan informasi yang diinginkan. Selain itu pula, Biro Humas tidak menunjukkan kemampuannya dalam melayani permintaan informasi. Hal ini dapat dilihat dari tidak diperlihatkannya ketersediaan informasi publik dari berbagai SKPD pada publik, sehingga publik tidak mengetahui secara jelas fungsi dari PPID utama.

Dalam kegiatan kehumasan, Biro Humas melakukan kegiatan pelayanan informasi dalam kegiatannya meng-handle pertanyaan yang ada pada e-mail maupun keluhan dari masyarakat yang masuk ke dalam e-mail pemerintah Provinsi Kalsel. Pengelolaan e-mail dilakukan oleh Biro Humas Provinsi Kalsel. Dalam praktiknya ketika mendapatkan e-mail masuk Biro Humas menjawab sesuai dengan apa yang diketahuinya dan menjawab pertanyaan yang memiliki dasar jawaban, namun apabila ragu atau tidak tahu sama sekali maka Biro Humas akan mengarahkan langsung kepada SKPD terkait sesuai dengan bidang yang dipertanyakan dalam $e$-mail publik tersebut.

Dalam Keputusan Kuasa Pengguna Anggaran Biro Humas Setda Provinsi Kalsel Tentang Pembentukan Tim Pengelola situs web resmi Pemerintah Provinsi Kalsel, tidak ada penjelasan bahwa tim pengelola merupakan juga pihak yang menjadi perantara atau penjawab pertanyaan saat terdapat pertanyaan dari e-mail. Tim pengelola website bertanggungjawab mengontrol data dan informasi yang dimuat saja pada situs website. Oleh karena itu tim pengelola lebih memilih website resmi Provinsi Kalsel hanya memakai e-mail sebagai alat komunikasi dua arahnya tidak 
berupa komentar yang dapat terlihat ditampilan website. Sampai saat ini belum ada Standar Operasional Prosedur (SOP) pelayanan dalam menangani pertanyaan dari masyarakat. Sehingga yang dilakukan Biro Humas adalah dengan menjawab sebisa dan sepengetahuan Biro Humas atau langsung diarahkan untuk menghubungi instansi ataupun SKPD terkait. Namun monitor maupun laporan terhadap e-mail dari masyarakat ini tidak pernah ada.

Terkait dengan pelayanan informasi oleh Biro Humas, kemampuan Biro Humas menciptakan komunikasi dua arah belum tercipta. Terbukti dari awal ketiga media komunikasi online yakni website, facebook, dan twitter tidak satupun yang digunakan oleh Biro Humas. Penggunaan website resmi Provinsi Kalsel ini masih bersifat satu arah hingga tidak ada kesempatan yang diberikan pada publik untuk mengemukakan pendapatnya. Biro Humas juga tidak pernah menanggapi pertanyaan ataupun komentar dari publik melalui facebook dan twitter. Hal ini disayangkan, sebab media sosial tersebut dapat menjadi alat yang mendekatkan pemerintah dengan publiknya. Informasi yang tersimpan di Biro Humas hanyalah informasi umum mengenai kegiatan pemerintahan terutama kegiatan pimpinan. Padahal sebagai PPID utama, kedudukannya saat ini strategis dalam pengumpulan informasi publik dari semua instansi serta melakukan pelayanan informasi bukan hanya lingkup sekretariat namun juga semua SKPD di Provinsi Kalimantan Selatan.

Uraian di atas terlihat jelas bahwa Biro Humas tidak menjalankan perannya seperti dikatakan oleh (Cutlip et al., 2006) Humas haruslah menjaga komunikasi dua arah dan memfasilitasi komunikasi dengan publiknya dan menjaga saluran komunikasi agar tetap terbuka.

\section{PENUTUP}

\section{Simpulan}

Ketidaktersediaan informasi dan dokumentasi yang memadai untuk diakses oleh masyarakat menjadi kelemahan Biro
Humas. Hal ini terkait dengan ketersediaan website PPID atau aplikasi PPID dari Biro Humas sebagai PPID utama Provinsi. Kemudian selain itu tidak maksimalnya koordinasi dan konsolidasi pengumpulan bahan informasi dan dokumentasi SKPD disebabkan oleh tidak ada kesinambungan yang nyata dari kegiatan yang telah dilakukan oleh Biro Humas, sehingga baik SKPD maupun publik tidak melihat keseriusan Biro Humas dalam melaksanakan tugasnya sebagai PPID Utama.

Ketidaktersediaan daftar informasi publik SKPD maupun Biro Humas serta tidak adanya interaktivitas pelayanan informasi oleh Biro Humas menjadi hal penting yang perlu diperhatikan, mengingat Biro Humas merupakan perantara komunikasi pemerintah dengan publiknya.

Penggunaan media online seperti website, facebook, twitter dan aplikasi android juga tidak dipergunakan oleh Biro Humas dengan baik terutama yang terkait keterbukaan informasi publik. Media online tersebut juga tidak dipergunakan untuk memberikan informasi mengenai keterbukaan informasi publik secara berkelanjutan. Semua media online tersebut hanya bersifat satu arah dan mengeluarkan berita yang seragam.

Peran Humas Pemerintah sebagai fasilitator komunikasi belum terlaksana dengan baik di Biro Humas Pemerintah Provinsi Kalimantan Selatan.

\section{Saran}

Rekomendasi dari penelitian ini adalah agar Biro Humas Provinsi Kalsel selaku PPID Utama dapat menjalankan perannya sebagai fasilitator komunikasi secara maksimal, selain itu Kementerian Komunikasi dan Informatika maupun Komisi Informasi Publik (KIP) agar selalu memantau perkembangan PPID di daerah, jika tidak maksimal dalam penyelenggaraannya bisa dibina. Selain itu dibutuhkan regulasi yang memberikan dasar yang kuat untuk mengomunikasikan segala bentuk informasi dari publik ke pemerintah, maupun sebaliknya. 


\section{DAFTAR PUSTAKA}

Anwar, M. K. and Oetojo S, A. (2004). Aplikasi Sistem Informasi Bagi Pemerintah Di Era Otonomi Daerah. Yogyakarta: Pustaka Pelajar.

Aprilia, S. N., Wijaya, A. F. and Suryadi, S. (2014). Efektivitas Website Sebagai Media E-Government dalam Meningkatkan Pelayanan Elektronik Pemerintah Daerah (Studi Pada Website Pemerintah Daerah Kabupaten Jombang). WACANA, Jurnal Sosial dan Humaniora, 17 (3), p.126-135. [Online]. Available at: http://wacana.ub.ac.id/index.php/wacana/ar ticle/view/313 [Accessed: 30 October 2015].

Boudreaux, J. (2005). A Quantitative Assessment of Public Relations Practitioners' Perceptions of Their Relationship with the Organization They Represent. University of South Florida. [Online]. Available at: http://scholarcommons.usf.edu/etd/2787/ [Accessed: 25 January 2015].

Cutlip, S. M., Center, A. H. and Broom, G. M. (2006). Effective Public Relations. 9th ed. Jakarta: Kencana.

Dozier, D. M. and Broom, G. M. (1995). Evolution of the Manager Role in Public Relations Practice. Journal of Public Relations Research, 7 (1), Lawrence Erlbaum Associates, Inc., p.3-26. [Online]. Available at: doi:10.1207/s1532754xjprr0701_02.

Dozier, D. M., Grunig, L. A. and Grunig, J. E. (1995). Manager's Guide to Excellence in
Public Relations and Communication Management. Mahwah, New Jersey: Lawrence Erlbaum Associates, Inc.

Habermas, J. (1991). The Structural Transformation of the Public Sphere: An Inquiry Into a Category of Bourgeois Society. MIT Press.

Hidayati, T. (2014). Peran Humas Dalam Implementasi Undang-Undang Nomor 14 Tahun 2008 Tentang Keterbukaan Informasi Publik di Badan Publik (Studi Kasus Pada Badan Pemeriksa Keuangan RI). Universitas Gadjah Mada. [Online]. Available at: http://etd.repository.ugm.ac.id/index.php?m od=penelitian_detail\&sub=PenelitianDetail \&act=view\&typ=html\&buku_id=69733 [Accessed: 24 May 2015].

Lee, J. (2010). 10year retrospect on stage models of e-Government: A qualitative metasynthesis. Government Information Quarterly, 27 (3), p.220-230. [Online]. Available at: doi:10.1016/j.giq.2009.12.009 [Accessed: 6 October 2015].

Lee, M., Neeley, G. and Stewart, K. (2012). The Practice of Government Public Relations. London: CRC Press.

Welkinson, D. (2012). Peran Humas Dewan Perwakilan Rakyat Republik Indonesia $\left(\begin{array}{ll}D P R & R I\end{array}\right)$ dalam Upaya Implementasi Undang-Undang No. 14 Tahun 2008 Tentang Keterbukaan Informasi Publik. Universitas Indonesia. [Online]. Available at:

http://lib.ui.ac.id/detail.jsp?id=20289266\&l okasi=lokal. 